\title{
Subak's Capacity Building: A Little Effort Toward Food Security and Sustainable Development Goals
}

\author{
Nyoman Utari Vipriyanti" ${ }^{\# 1}$, Cening Kardi ${ }^{\# 2}$ \\ \# Department of Agribusiness, Mahasaraswati Denpasar University, Kamboja Street, Denpasar, Bali, Indonesia \\ E-mail: ${ }^{1}$ mangtiutari@yahoo.com, ${ }^{2}$ ceningkrd@gmail.com
}

\begin{abstract}
Nowadays, there are strong demands on the organic farming. Organic farming as a part of organic agriculture builds on the harmony of nature, through optimizing the use of biodiversity and natural intake of the recycling process of natural materials, in order to reach sustainability, healthy food production and energy saving. Effort to change the behavior of farmers who are accustomed to using inorganic material to organic farming was not easy. This study aimed to determine (1) the costs and benefit of local varieties cultivation of paddy, Cicih Gondrong, with semi-organic pattern; and (2) the farmer perception toward Cicih Gondrong semi-organic pattern cultivation. This research used plot demonstration (demplots) and survey methods. The results showed that semi-organic cultivation of paddy Cicih Gondrong, economically profitable. There are significant changes in the perception of farmers on the management of local varieties of rice before and after the demonstration carried out. Government role is needed to make organic farming program running well especially to provide assistance and infrastructure support.
\end{abstract}

Keywords - Capacity Building, Organic Farming, Sustainable Agriculture, Farmer Perception, Government Role

\section{INTRODUCTION}

Bali, one of small islands in Indonesia, has a beautiful and unique Tradition-Religion-Culture-Aspiration society that well known in all around the world. Unfortunately, there is tradeoff between tourism development to increase community welfare and enhance agriculture activities to sustain environmental. Nowadays, the best option is to develop tourism without sacrificing agricultural sector and environment such as agro tourism development program.

Agriculture that is developed to be agro tourism includes a smallholder agriculture, plantation, forestry, animal husbandry and fisheries. So that agro tourism development in Bali goals are building an integrated system of agriculture and tourism activities to develop the tourism sector as well the agricultural sector in same time maintaining environmental sustainability and improving the welfare of farmers. This program will be encouraged by high quality of natural resources of Bali which has potential in paddy cultivation with traditional religious institution called Subak.

Buleleng Regency is one area in Bali that has high potential for paddy farming with well known product of rice: Sudaji Rice. This Rice has a unique taste with bright white color and high price. Location of Sudaji village is $9 \mathrm{~km}$ from the Capital City District (Keloncing); $16 \mathrm{~km}$ from the Capital District (Singaraja); and $88 \mathrm{~km}$ from the provincial capital of Bali (Denpasar). This Village is hilly topography with altitude around 450-560 meters above the sea. The level of rainfall is $2000 \mathrm{~mm}$ / year, temperatures between 2528 o C. Sudaji location can be seen in Figure 1. This indicates that the characteristic of agriculture land in this village is very fertile with abundant of irrigation water.

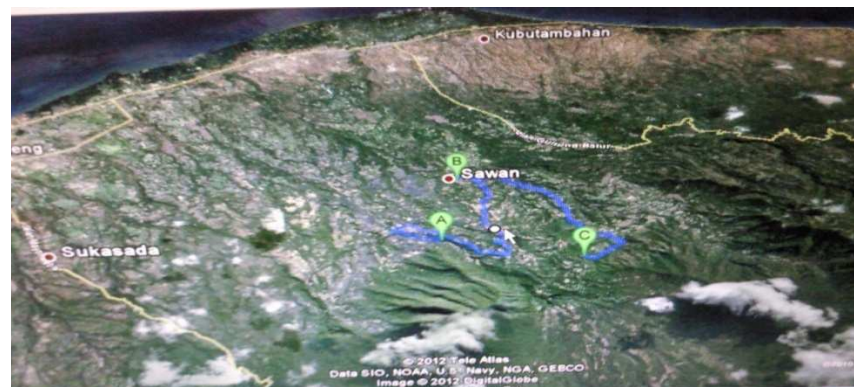

Fig. 1. Sudaji Location Map

Sudaji Rice has a good brand in Bali because it has good quality and fluffier, so it has a very high demand at high price. Unfortunately, green revolution encouraged farmer to use chemical intake intensively that resulted in low quality of Sudaji rice. In the other hand, tourist more interested in organic product. So it need many efforts to restore the image of Sudaji rice e.g reintroducing the application of 
organic based rice farming technologies and local varieties of Sudaji rice: Cicih Gondrong.

Organic-based farming practices allegedly able to contribute to the development of rural development. Integrated organic farming represents a chance at all levels, promote rural economic development in a sustainable manner. So many new employment opportunities will grow as a result of organic-based agricultural growth. In an effort to embody and utilize the concepts of environmentally friendly agriculture (organic based) which rely on farmland biodiversity, it is necessary to increase the net return programs implemented based organic rice through revolving funds and assistance directly implemented by the farming community in the village Subak Sudaji.

\section{LONG TERM RICE DEVELOPMENT STRATEGY MAP FOR LOCAL VARIETY CICIH GONDRONG}

In order to increase the benefit of organic rice farming program to enhance the well-being of farmers in Sudaji village especially in implementation of organic technology, there are some consideration such as:

1) Vision and Mission expect that Bali agriculture will achieve sustainable agricultural systems, which is able to guarantee the food security system, dynamic and advanced agribusiness system,

2) In 21st century, awareness of people around the world to realize the danger of synthetic chemicals in agriculture because it has led to the destruction of nature and the environment, particularly in agricultural ecosystems, such as the reduction of a variety of micro-organisms in the soil, killing a variety of natural enemies, increase pest populations and plant diseases, pollution of soil, water and air. Especially of that is the synthetic chemical residues in food is very harmful to human health.

3) Changes in consumer preferences continue with demanding better quality in agricultural product than previous products involving aspects of quality, nutritional composition, safety consuming, and result from activities that do not harm the environment, biodiversity, and human rights are not violated.

4) Expected model to increase the added value of tourism in Bali such as presenting local dish that safe for direct consumption, have a high nutrient content and environmentally friendly. It means agriculture product with organic-based farming.

5) Metaphysical activities were inspired by local wisdom such as Ahimsa, Tatwamasi, and Tri Hitha Karana. Philosophical Teachings are required to always maintain balance and fertility Rwa bhineda (two things that seem contradictory that that make life happens). In this case the natural enemy and agro eco systems are manifestation of the Rwa bhineda should always be kept in balance. Way is through the renewal of the organic-based agriculture.

6) Former, culture and religion are very tight in Bali especially in improvement fertilization of land, crop rotation, and conservation efforts. Recently this norm is weak due to the demands of modern agriculture, so it needs revitalization.
7) Social Capital sourced from the dynamics of socioreligious groups: Subak, Banjar and small traditional organization based on activities called Seka-strongly supports renewal of organic-based agriculture in Bali.

The achievement of this program will drive achievement of food security in Bali Province. Food security was defined in the 1974 World Food Summit as availability at all times of adequate world food supplies of basic foodstuffs to sustain a steady expansion of food consumption and to offset fluctuations in production and prices. Food security is a flexible concept as reflected in the many attempts at definition in research and policy usage. Even a decade ago, there were about 200 definitions in published writings., Whenever the concept is introduced in the title of a study or its objectives, it is necessary to look closely to establish the explicit or implied definition.

Food security as a concept originated only in the mid1970s, in the discussions of international food problems at a time of global food crisis. The initial focus of attention was primarily on food supply problems - of assuring the availability and to some degree the price stability of basic foodstuffs at the international and national level. That supply-side, international and institutional set of concerns reflected the changing organization of the global food economy that had precipitated the crisis. A process of international negotiation followed, leading to the World Food Conference of 1974, and a new set of institutional arrangements covering information, resources for promoting food security and forums for dialogue on policy issues.

Food security exists when all people, at all times, have physical, social and economic access to sufficient, safe and nutritious food which meets their dietary needs and food preferences for an active and healthy life. Household food security is the application of this concept to the family level, with individuals within households as the focus of concern. Food insecurity exists when people do not have adequate physical, social or economic access to food as defined above.

\section{METHOD}

This study is an experimental study involving 5 farmers with land cultivation area 3 acres. Farmer plant local variety of paddy, Cicih Gondrong, with organic fertilizer applications. This research carried out during the third growing season, September 2013. Two type of data were analyzed to know about benefit cost ratio of organic based cultivation of local variety of paddy. Qualitative data was used to describe about reintroducing process of local variety of paddy, Cicih Gondrong.

\section{RESULT AND DISCUSSION}

\section{A. Implementation Program Model}

Model of program execution using a packet-based Organic Rice Cultivation Technology (P3BO Unmas) with assistance by the technical officer and an expert of the team member. Long-term development strategy of organic Rice at Sudaji village presented at Figure 2 


\begin{tabular}{|c|c|c|c|}
\hline \multicolumn{2}{|c|}{ Organic farming Method: } & \multicolumn{2}{|c|}{ Community approach by Participatory Rural Apraisal (PRA) : } \\
\hline 1. Land & 4. $\quad$ Pesticide & 1. Start & 4. Application Technology \\
\hline a. minimal processing & a. Natural & a. Cooperation & a. Measurement \\
\hline b. conservation & b. Integrated Pest Management & b. Initial Situation Analysis & b. Evaluation \\
\hline c. mulche processing & c. Biological Agents & c. Awareness mobilization & 5. Dissemination \\
\hline & 5. Labor & 2. Technology aplication & Basic Idea \\
\hline 2. Seed & a. Man & a. Priorityldentification & Result \\
\hline a. Local variety & b. livestock & b. Academic Identification & Networking \\
\hline b. Safe high yield variety & c. Mini Tractor & b. Info lokal & 6. Process \\
\hline & 6. Management & Penyaringan opsi & Organization \\
\hline 3. Fertilizer & a. Long Term & 3. Technology Application Design & Development \\
\hline a. Kascing & b. Ecology and Economic & a. Trial and Error Assesment & Documentation of \\
\hline b. Bokashi & Orientation & Test of Design & Technology Applicaton \\
\hline c. Kompos Mol & $\begin{array}{l}\text { c. Local wisdom and global } \\
\text { perspective }\end{array}$ & $\begin{array}{l}\text { c. Evaluation of Design } \\
\text { b. evaluation }\end{array}$ & $\begin{array}{ll}\text { Result } \\
\text { b. } & \text { Monitoring of } \\
\text { sustainability of effect }\end{array}$ \\
\hline
\end{tabular}

Fig. 2 Map of long-term development strategy of organic Rice at Sudaji village.

\section{B. Benefit and Cost Analysis}

The following are the cost of return predictions based local cultivars of rice farming in the village Sudaji organic. The analysis was made for the land area per one hectare, the value or price of a used applies to the local area.

TABLE I

Cost AND Benefit ANALysis of LoCal Cultuval of PadDy CiciH GONDRONG AT SUBAK DUKUH DESA SUDAJI

\begin{tabular}{|c|c|c|c|c|}
\hline \multicolumn{5}{|c|}{ COST \& RETURN PER HEKTAR } \\
\hline No & Kind of Input/Cost & Quantity & Price (Rp) & $\begin{array}{c}\text { QuantityxPrice } \\
\text { (Rp) }\end{array}$ \\
\hline 1 & Local Seed & $30 \mathrm{~kg}$ & $36000 / \mathrm{kg}$ & 1080000 \\
\hline 2 & Organic Fertilizer & 4,5 ton & $2800000 /$ ton & 12600000 \\
\hline 3 & Biourine & 1301 & $4000 / 1$ & 520000 \\
\hline 4 & Liquid Fertilizer & 201 & $90000 / 1$ & 1800000 \\
\hline 5 & Starter N & $60 \mathrm{~kg}$ & $5000 / \mathrm{kg}$ & 300000 \\
\hline 6 & $\begin{array}{l}\text { Biological } \\
\text { Pestizide }\end{array}$ & & & 3400000 \\
\hline 7 & $\begin{array}{ll}\text { Man power } \\
> & \begin{array}{l}\text { Soil } \\
\text { processing }\end{array} \\
> & \text { Plantation } \\
> & \text { Replanting } \\
> & \begin{array}{l}\text { Eradication } \\
\text { of Pest }\end{array} \\
> & \text { Fertilization } \\
> & \text { Spraying } \\
> & \text { Harvest }\end{array}$ & $\begin{array}{c}40 \mathrm{HOK} \\
32 \mathrm{HOK} \\
18 \mathrm{HOK} \\
14 \mathrm{HOK} \\
26 \mathrm{HOK} \\
8 \mathrm{HOK} \\
42 \mathrm{HOK}\end{array}$ & $\begin{array}{l}45000 / \mathrm{HOK} \\
45000 / \mathrm{HOK} \\
45000 / \mathrm{HOK} \\
45000 / \mathrm{HOK} \\
45000 / \mathrm{HOK} \\
45000 / \mathrm{HOK} \\
45000 / \mathrm{HOK}\end{array}$ & $\begin{array}{r}1800000 \\
1440000 \\
810000 \\
630000 \\
1170000 \\
360000 \\
1890000\end{array}$ \\
\hline 8 & TOTAL COST & & & 27800000 \\
\hline 9 & RETURN & $\begin{array}{c}5800 \mathrm{~kg} \\
(\mathrm{gkg})\end{array}$ & $9800 / \mathrm{kg}$ & 56840000 \\
\hline 10 & Benefit & & & 29040000 \\
\hline
\end{tabular}

Source: Primary Data, 2013

In the early stages (first production period) of organic cultivation was not perfectly formed. The average yield per hectare of rice fields were $5800 \mathrm{Kg}$ dry milled grain or IDR 29.04 million. Gradually, the perfect organic land and ecosystem balance occurs as preservation of biodiversity.

The amount of initial investment is 27.80 million dollars per hectare. Bank rate calculated is $r=13 \%$ / year or $4.33 \%$ / planting. Value for money invested 27.80 million dollars during the growing season to-1, at the end of the growing season 9th, will have a total value of money now (NPV) of
265.74 million dollars. Cash Flow of Nine Planting period presented at Table 2 .

TABLE II

CASH-FLOW OF 9 PLANTING PERIOD OF ORGaNIC PADDY PER HA (IDR MILLION)

\begin{tabular}{|c|c|c|c|c|c|c|}
\hline $\begin{array}{c}\text { Planting } \\
\text { period } \\
-\mathrm{t}\end{array}$ & $\begin{array}{c}\text { COST } \\
\text { Period- } \\
\mathrm{t}\end{array}$ & $\begin{array}{c}\text { BENEFIT } \\
\text { Period- } \\
\mathrm{t}\end{array}$ & PFt & $\begin{array}{c}\text { (COSTt) } \\
\text { PFt }\end{array}$ & $\begin{array}{c}\text { (BENEFITt } \\
\text { PFt }\end{array}$ & NPVt \\
\hline 1 & 27,80 & 56,84 & 0,958 & 26,63 & 54,45 & 27,82 \\
\hline 2 & 27,15 & 57,51 & 0,919 & 24,95 & 52,85 & 27,90 \\
\hline 3 & 25,85 & 58,87 & 0,881 & 22,77 & 51,86 & 29,09 \\
\hline 4 & 25,20 & 60,22 & 0,844 & 21,27 & 50,83 & 29,56 \\
\hline 5 & 24,41 & 61,57 & 0,809 & 19,75 & 49,81 & 30,06 \\
\hline 6 & 23,90 & 62,93 & 0,775 & 18,52 & 48,77 & 30,25 \\
\hline 7 & 23,11 & 63,60 & 0,743 & 17,17 & 47,25 & 30,08 \\
\hline 8 & 22,50 & 64,96 & 0,712 & 16,02 & 46,25 & 30,23 \\
\hline 9 & 21,29 & 66,31 & 0,683 & 14,54 & 45,29 & 30,75 \\
\hline TOTAL & 221,21 & 552,81 & 7,32 & 181,63 & 447,37 & 265,74 \\
\hline
\end{tabular}

Source: Primary Data, 2013

\section{CONCLUSIONS}

Food security is a multi-dimensional phenomenon. National and international political action seems to require the identification of simple deficits that can be the basis for setting of targets, thus necessitating the adoption of single, simplistic indicators for policy analysis. Reintroducing and replanting local variety of Paddy: Cicih Gondrong could drive Food Security, Improving Quality of Environment and Increasing welfare of Farmer.

\section{REFERENCES}

[1] Arsana, D., A.A. Wiguna dan H. Sembiring. Transformasi Inovasi Teknologi Tanaman Padi Dengan Pendekatan Ekofarming pada Ekosistem Subak di Bali. Denpasar: Balai Pengkajian Teknologi Pertanian Bali. 2011. 
[2] Graeme, MR., Rice Farming in Bali: Organic Production and Market Challenges. Critical Asian Studies, 43: 1, 69 - 92 (Online publication date: 13 April 2011). 2011.

[3] Kardi, C., I.K. Widnyana dan W.G. Hadiwijaya. Model Revitalisasi Metafisik Pertanian dalam Upaya Menopang Pertanian Berkelanjutan dan Pariwisata Kerakyatan Di Kabupaten Buleleng (Laporan Penelitian Hibah Bersaing Tahun II). Denpasar: LPPM Universitas Mahasaraswati Denpasar. 2013.

[4] Kardi, C., 2012. Upaya Peningkatan Daya Saing Subak dalam Pengembangan Pertanian Berekelanjutan dan Pariwisata Kerakyatan di Kabupaten Buleleng. Jurnal Agrimeta Vol. 2 No. 3.

[5] Namayudha, I.B. Upacara Ngusaba Nini. Denpasar: Parisada Hindu Darma. 2009.

[6] Salikin, K.A. Sistem Pertanian Berkelanjutan. Yogyakarta: Penerbit Kanisius. 2003.

[7] Utari, N., P. Sujana, dan M. Tamba. Kontribusi Pariwisata terhadap Sektor Pertanian Di Bali. Denpasar: Dinas Pariwisata Provinsi Bali. 2010
[8] Utari, N., G.P. Agung dan M. Tamba. Road Map Investasi Di Provinsi Bali, Denpasar: Badan enanaman Modal Provinsi Bali. 2011

[9] Utari, N., I.K. Arnawa, C. Kardi dan I.K. Widnyana. Pengembangan Jalur Agrowisata Kaje-Kelod di Buleleng Barat-Bali (Laporan Penelitian MP3EI Tahun II). Denpasar: LPPM Universitas Mahasaraswati Denpasar. 2013.

[10] Utari, N., C. Kardi, I.K. Arnawa, dan I.K. Widnyana. Demplot Budidaya Padi Kultivar Lokal Cicih Gondrong (Penelitian Kerjasama Unmas Denpasar dengan Sumatra Education Research Valley). Denpasar: LPPM Universitas Mahasaraswati Denpasar. 2013.

[11] Widnyana, I.K., P. Sujana, dan Eka Martiningsih. Peningkatan Produktivitas Padi Berbasis Organic (P3BO) dalam menunjang pariwisata di Bali. Denpasar: LPPM Universitas Mahasaraswati Denpasar. 2009.

[12] Wiguna, A.A. Modifikasi SRI dengan Optimlisasi Setempat. Denpasar: Balai Pengkajian Teknologi Pertanian Bali. 2007. 